\title{
Profile of a global contagion: SARS-CoV-2
}

\author{
Sunethra Gunasena \\ Department of Microbiology, Faculty of Medicine, University of Ruhuna, Galle, Sri Lanka.
}

Correspondence: Dr. Sunethra Gunasena

e-mail: sunethra.gunasena@gmail.com

(7) https://orcid.org/0000-0001-8332-9079

\section{Introduction}

In December 2019, number of cases of pneumonia of unknown aetiology was reported from Wuhan, Hubei Province, China to the World Health Organization (WHO). Clinical presentations were very much like that of viral pneumonia. In addition to the increase in number, cases were reported from other provinces in China. Thailand reported first laboratory confirmed imported case on $13^{\text {th }}$ January 2020 followed by Japan and Republic of Korea (1).

Deep sequencing of lower respiratory tract samples collected from affected patients identified a coronavirus not detected before and was named as 2019 Novel coronavirus (2019-nCoV) (1). Further genetic studies indicated that this virus is genetically linked to the virus that caused severe acute respiratory syndrome (SARS) epidemic in 2002 2003 and International Committee on Taxonomy of Viruses (ICTV) named it as "Severe Acute Respiratory Syndrome coronavirus 2 (SARS-CoV2). WHO announced the disease caused by SARSCoV-2 as "Coronavirus disease 2019 or COVID-19" (2).

Spread of the virus within China and importation of the virus to other countries led WHO to declare the outbreak as "Public health emergency of international importance" (3). With the establish-ment of outbreaks in many countries WHO declared COVID-19 as a Pandemic on $11^{\text {th }}$ March 2020 (3).

\section{Current global situation}

COVID-19 pandemic has affected more than 190 countries with rapidly changing case load and number of deaths. WHO has reported (accessed on $28^{\text {th }}$ March 2020) more than 570,000 cases with more than 26,000 deaths around the world (4).
China has reported 135 new cases with 3 new deaths during last 24 hours indicating the epidemic has been controlled. Of the European countries, highest number coming from is Italy with 86,498 cases and 9136 deaths. Spain, France and Germany are the other worst affected European countries. Even though, Germany has reported nearly 50,000 cases, number of deaths is only 325 . Rapidly expanding epidemic has been reported from United States with 85,228 cases and 1243 deaths (4). Situation appears to be out of control with more countries reporting cases and countries already affected having rapidly increasing numbers and deaths.

\section{Situation in Sri Lanka}

Epidemiology Unit, Ministry of Health, Sri Lanka in its latest report released on $30^{\text {th }}$ March 2020 at 7.00 p.m. declared that 122 COVID-19 patients (including three foreigners) has been laboratory confirmed. Of this, 14 patients have recovered with two reported deaths and 104 patients are under observation (5). COVID-19 exposure history published by the Epidemiology Unit of Sri Lanka provides interesting information. Transmission links has been identified to all most all of cases and it indicates the transmission is confined to family contacts and contacts of imported cases with no community transmission (6).

\section{The Virus}

The virus SARS-CoV-2 with the SARS-CoV and MERS-CoV are members of the genus Beta coronavirus of the family Coronaviridae. All three viruses are bat viruses and once humans are infected, human to human transmission can occur (7). 


\section{Transmission}

Human to human transmission occurs through respiratory route. Transmission can occur in close personal contact (within 6 feet of a sick person) via droplets generated by coughing, sneezing or by direct contact with infected respiratory secretions on the mucous membrane of mouth, nose or eye. Transmission also occurs via indirect contact with contaminated surfaces or objects (7).

\section{Clinical presentation}

Incubation period of COVID-19 vary from 0 to 14 days on average 5-6 days (8). It is estimated that $80 \%$ of the infected patients have asymptomatic or mild disease and does not seek health care. Another $14 \%$ have severe illness and $6 \%$ has critical illness and these two groups are in contact with health care system (9). Infectivity of asymptomatic patients and the importance of them in the transmission of the virus in the community remains uncertain.

Fever, sore throat and dry cough is considered the common symptoms of COVID-19. Breathlessness is commonly seen in critically ill patients. Sputum production, headache and diarrhea is seen less commonly. Leucopenia and evidence of renal impairment may also be there in a few (10). China has reported a $2.3 \%$ case fatality rate (CFR) for COVID-19 (11). However, WHO estimates lower infection fatality rate of $0.3-1 \%$ (8).

Preliminary data from USA showed that number of cases and the severity (as defined by hospitalisation and ICU admission) increases with age (12). A study from China also reported that $86.6 \%$ of COVID-19 cases were from 30 - 79 years age group (11).

Similarly, CFR increases with age and with coexisting serious health conditions. Report indicates $45 \%$ hospitalisation, $53 \%$ of ICU admissions and $80 \%$ of deaths occurred in $\geq 65$ years age group (12).

Data from Epidemiology Unit of Sri Lanka showed that highest number of cases $(33 \%)$ reported from age group 41 - 50 years and only $9 \%$ reported from less than 20 years age group. Interestingly it appears the elderly population has been relatively spared $(61-70$ years $6.6 \%$ and $>70$ years $1.8 \%)(13)$.

\section{Period of infectivity}

From few virological studies performed, the period of infectivity has been estimated. They indicate that the patients are infectious $1-2$ days before the onset of symptoms lasting for 10 days or more after the onset of symptoms (14). This reiterate the importance of isolation of the patient following onset of symptoms and the tracing and isolation of contacts who have been exposed to the patient during the incubation period. WHO identify the period of exposure as 2 days before to 14 days after onset of symptoms in defining the contacts (4).

\section{Minimizing the adverse effect of the pandemic}

WHO has identified strategic objectives in the context of ongoing COVID - 19 pandemic namely,

1) Interrupt human-human transmission,

2) Identify, isolate and care for patients early,

3) Identify and reduce transmission from animals,

4) Address crucial unknowns e.g. clinical severity, extent of transmission, treatment options etc. 5) Communicate critical risk and event information,

6) Minimize social and economic impact (15).

By implementation of quarantine, social distancing and isolation of infected patients China was able to control the COVID-19 epidemic by early March 2020 (16). Early government action and social distancing measures taken by the individuals helped to keep the situation in Singapore and Hong Kong under control.

An article on the influence of mitigation measures on the course of COVID-19 epidemic, the authors comment that in comparison to new strain of influenza A, COVID-19 epidemic slower in initial spread, has a more drown out course and the effect of seasonality is unknown (17).

Mandatory quarantine is implemented for the exposed contacts and for returnees from affected countries. Early identification, isolation and management of patients in health care institutions or at home is important. Social distancing is implemented by stopping mass gathering (both public and private), closure of educational institutions, workplaces, isolation of households, areas, towns where infected patients were detected and more extensive scale social distancing like 
"lockdown." These measures will help to minimize the human - human transmission, bring the case load to a manageable level so that it will not overwhelm the health care system (17).

Recommendations of WHO on prevention and mitigation of this pandemic also addressed exposure of health care workers (HCW) to the patients by way of risk assessment and management in context of COVID-19 (18).

It is the responsibility of the government and the policy makers to decide and implement the strategies to control the COVID-19 epidemic and to minimize its social and economic impact. However, the success of these measures also depends on the voluntary implementation of these strategies by the individuals.

\section{References}

1. World Health Organization. Situation report 1 on $21^{\text {st }}$ January 2020. https://www.who.int/emergencies/ diseases/novel-coronavirus-2019/situation-reports/

2. World Health Organization. Naming the coronavirus disease and the virus that causes it. https://www.who.int/ emergencies/diseases/novel-coronavirus-2019/technicalguidance/naming-the-coronavirus-disease-(covid-2019)and-the-virus-that-causes-it.

3. World Health Organization. Rolling updates on coronavirus disease (COVID-19). https://www.who.int/ emergencies/ diseases/novel-coronavirus-2019/events-asthey-happen.

4. World Health Organization. Situation report 68 on $28^{\text {th }}$ March 2020. https://www.who.int/emergencies/ diseases/novel-coronavirus-2019/situation-reports/

5. National Epidemiological Report, Epidemiology Unit, Sri Lanka dated 30.03.2020. http://www.epid.gov.lk/web/ index.php?lang=en

6. Epidemiology Unit. COVID-19 Exposure history updated on 27.03.2020. http://www.epid.gov.lk/web/

7. Centers for Disease Control and prevention (CDC), USA. How it spreads. https://www.cdc.gov/coronavirus/2019ncov/prepare/transmission.html

8. World Health Organization. Situation report 30 on $19^{\text {th }}$ February2020. https://www.who.int/emergencies/ diseases/novel-coronavirus-2019/situation-reports/
9. European Centre for Disease Prevention and Control. Daily risk assessment on COVID-19. https://www.ecdc.europa. eu/en/current-risk-assessment-novel-coronavirussituation.

10. Huang Chaolin, Wang Yeming, Li Xingwang et al. Clinical features of patients infected with 2019 novel coronavirus in Wuhan, China, The Lancet 2019; 395: 10223: 497-. DOI: https://doi.org/10.1016/S0140-6736(20)30183-5.

11. Novel Coronavirus Pneumonia Emergency Response Epidemiology Team. The epidemiological characteristics of an outbreak of 2019 novel coronavirus diseases (COVID-19) in China [Chinese]. Chinese Center for Disease Control and Prevention Weekly 2020; 41:145-51.

12 Centers for Disease Control and prevention (CDC), USA. Severe outcomes among patients with coronavirus disease 2019 (COVID-19) United States, MMRW, February 12 March 16, 2020. https://www.cdc.gov/mmwr/ volumes/69/wr/mm6912e2.htm

13. Epidemiology Unit. Situation report 61 on 28.03.2020. http://www.epid.gov.lk/web/

14. Zou L, Ruan F, Huang M, et al. SARS-CoV-2 viral load in upper respiratory specimens of infected patients. New England Journal of Medicine 2020; published online Feb 19. DOI: 10.1056/NEJMc2001737.

15. World Health Organization. Situation report 07 on $27^{\text {th }}$ January 2020. https://www.who.int/emergencies/ diseases/novel-coronavirus-2019/situation-reports/

16. World Health Organization. Situation report 44 on $4^{\text {th }}$ March 2020. https://www.who.int/emergencies/ diseases/novel-coronavirus-2019/situation-reports/

17. Roy M Anderson, Hans Heesterbeek, Don Klinkenberg, $T$ Déirdre Hollingsworth. How will country-based mitigation measures influence the course of COVID - 19 epidemic? The Lancet 2020 March, 395; 10228: 931-934. DOI: https://doi.org/10.1016/S0140-6736(20)30567-5.

18. World Health Organization. Situation report 53 on $13^{\text {th }}$ March 2020. https://www.who.int/emergencies/diseases/ novel-coronavirus-2019/situation-reports/ 